NBER WORKING PAPER SERIES

\title{
HARD TARGETS: \\ THEORY AND EVIDENCE ON SUICIDE ATTACKS
}

\author{
Eli Berman \\ David D. Laitin \\ Working Paper 11740 \\ http://www.nber.org/papers/w11740 \\ NATIONAL BUREAU OF ECONOMIC RESEARCH \\ 1050 Massachusetts Avenue \\ Cambridge, MA 02138 \\ November 2005
}

We thank Eva Meyersson Milgrom for organizing the Stanford suicide terrorism project and for her foresight in matchmaking this collaboration. We also thank Barak Bouks for research assistance. This version benefitted from discussions with Larry Iannaccone, Gershon Shafir, Mahmoud Al-Gamal. James Fearon, Peter Katzenstein, Alan Krueger, Howard Rosenthal, and participants in seminars at the University of Chicago and at Stanford University. Berman acknowledges support of NSF grant 0214701 through the NBER. The views expressed herein are those of the author(s) and do not necessarily reflect the views of the National Bureau of Economic Research.

(O2005 by Eli Berman and David D. Laitin. All rights reserved. Short sections of text, not to exceed two paragraphs, may be quoted without explicit permission provided that full credit, including $\odot$ notice, is given to the source. 
Identifying Age, Cohort and Period Effects in Scientific Research Productivity: Discussion and Eli Berman and David D. Laitin

NBER Working Paper No. 11740

November 2005

JEL No. H56, Z12, D71, D74, H40

\begin{abstract}
Who chooses suicide attacks? Though rebels typically target poor countries, suicide attacks are just as likely to target rich democracies. Though many groups have grievances, suicide attacks are favored by the radical religious. Though rebels often kill coreligionists, they seldom use suicide attacks to do so. We model the choice of tactics by rebels, bearing in mind that a successful suicide attack imposes the ultimate cost on the attacker and the organization. We first ask what a suicide attacker would have to believe to be deemed rational. We then embed the attacker and other operatives in a club good model which emphasizes the function of voluntary religious organizations as providers of benign local public goods. The sacrifices which these groups demand solve a freerider problem in the cooperative production of public goods. These sacrifices make clubs well suited for organizing suicide attacks, a tactic in which defection by operatives (including the attacker) endangers the entire organization. The model also analyzes the choice of suicide attacks as a tactic, predicting that suicide will be used when targets are well protected and when damage is great. Those predictions are consistent with the patterns described above. The model has testable implications for tactic choice of terrorists and for damage achieved by different types of terrorists, which we find to be consistent with the data.
\end{abstract}

\author{
Eli Berman \\ Department of Economics, 508 \\ University of California, San Diego \\ 9500 Gilman Drive \\ La Jolla, CA 92093 \\ and NBER \\ elib@ucsd.edu \\ David Laitin \\ Political Science \\ Encina Hall West, Room 100 \\ Stanford University \\ Stanford, CA 94305-6044 \\ dlaitin@stanford.edu
}


Berman and Laitin, "Hard Targets" p. 2

\section{Introduction}

The suicide attack is a gruesome tactic of rebellion which imposes the ultimate cost on the attacker. Why would leaders of rebellions employ it? Under what conditions will suicide attacks succeed? What kinds of rebels use it most effectively? Our answers are as follows. Where states are strong and their targets well-protected, rebel organizations cannot successfully use standard insurgency tactics. Yet under those conditions, suicide attacks can be devastatingly effective. While recruiting suicide attackers is easier than many surmise, recruiting operatives resistant to defection in these high-stakes attacks is a first-order tactical problem. Radical religious organizations that require sacrifices as signals of commitment, and in return provide concrete benefits, are better able to insulate themselves against defection. We rely on a club model to analyze such organizations, explaining four patterns in data on suicide attacks: (a) their targets are in higher income countries than those of standard insurgencies; (b) perpetrators and victims are generally of different religions; (c) "hybrid" organizations which provide benign local public goods such as education and welfare are more effective killing operations; and (d) suicide attacks are more likely against hard targets - targets for which an effective attack makes escape unlikely.

Our argument draws on two literatures, the political science of insurgencies and the economics of religion. In section 1 we use a newly constructed dataset (described in the Appendix) to present two patterns. First, compared to the environmental conditions favoring insurgency (Fearon and Laitin 2003) the tactic of suicide attacks tends to be chosen when targets are harder, while conventional insurgency is chosen when targets are soft (i.e., their destruction is possible with lesser risk to attackers). Second, suicide attacks tend to be chosen when the perpetrator and target are of different religions.

In section 2, we provide a theoretical foundation for both patterns. To do so, we first outline the beliefs that suicide attackers would need to hold for their actions to be deemed rational (Wintrobe 2002). We then consider the attacker and his organization in a rational choice framework. The model, relying on Iannaccone (1992) and Berman (2003), shows why "clubs" of a certain type (most easily formed through religious membership) 
are able to organize high-stakes suicide attacks despite strong incentives for operatives to defect.

Tactics, our formal model shows, vary across targets. As targets are hardened (i.e., chances of escape are reduced) suicide attacks are increasingly favored because they allow even well defended targets to be destroyed while preventing apprehension of the attacker and exposure of the network. For hard enough targets this advantage outweighs the cost of losing a member (the attacker) with certainty. Thus as states become more powerful and better able to defend targets, suicide attacks are used more often.

In section 3, we test implications of the model. First, suicide attacks are in general more likely to be used against well protected (hard) targets than against poorly-defended (soft) targets. Second, hybrid organizations are able to carry out suicide attacks more effectively because they have better mechanisms to prevent defection.

In the conclusion we address an anomaly. The Tamils in Sri Lanka perpetrate the second largest number of suicide attacks in our sample period. Although most of the attacks are interreligious, the perpetrators are not members of a radical religious club. We then suggest future empirical extensions that follow from the theory. We also discuss the key policy implication: the better states and markets are at providing social services, the harder it is for insurgencies to organize around a social-service provision base and conduct high stakes attacks without fear of defection. 


\section{Section 1. Background and Conjectures}

Insurgency

Insurgency is a technology of rebellion through guerilla warfare that has been successful in challenging regime domination in many countries. It has been hitched to various ideologies: communism, nationalism, religious fanaticism, and even to no ideology at all (the FARC in Colombia)! Between1945 and 1999, 127 civil wars in 73 different countries accounted for more than sixteen million deaths. ${ }^{1}$ Many of these relied upon the technology of rural insurgency.

Fearon and Laitin (2003, hereafter FL) show that civil wars cannot be explained by: (a) level of grievances in the society or (b) degree of ethnic or religious difference or any form of civilizational clash. Rather, the best predictors of civil war are conditions favoring the success of the rural insurgency technology: bad roads, rough terrain, poor state armies, lack of more remunerative employment for young men (as compared to being an insurgent), and weak and new governments. ${ }^{2}$

This research yields an insurgent profile. He is poor (with few alternative career paths than insurgency), from an impoverished country (but not necessarily a backward region within that country, as internal migration from a poor to a rich region is an attractive alternative to insurgency). This country is likely to have a considerable swath of rough terrain not easily accessible by the armed forces of the state. Rough terrain is important for insurgency survival in part because of the inherent difficulty of the terrain, but is magnified in low GDP/capita countries, as GDP/capita is a good proxy for a weak

\footnotetext{
${ }^{1}$. Civil war is a violent conflict between an organized militia and the armies of a state, involving contest for control over a region or the entire territory of the state. Enumeration requires at least 1,000 deaths recorded as a direct result, concentrated temporally close to its onset, with at least 10 percent of the deaths being civilians or soldiers on the government's side. For details see Fearon and Laitin (2003).

2. FL rely on two datasets: a revised MAR group/country dataset of over 400

minority/ethnic/religious/regional groups in over 100 countries; and a country/year data set of all countries of over 500,000 in every year since 1945. Replication data are available at http://www.stanford.edu/group/ethnic/workingpapers/papers.htm].
} 
state with a badly organized, low information army, an army that would not perform well under harsh conditions. Armies in poor states, for lack of reliable information, rely heavily on indiscriminate bombing that has the unintended effect of enriching the pool of potential recruits, thereby helping to sustain the insurgency. Recruits are typically young men, unemployed, ill-educated, and therefore only remotely involved in grasping the ideological message of leadership. ${ }^{3}$

\section{Suicide Attacks as a Tactic}

Guerrilla warfare by insurgents encompasses a variety of tactics - most typically a network of self-sustaining rural militias that first intimidate populations and then govern them, providing alternate sovereignty. Suicide attacks -in which the attacker will almost certainly die if the attack succeeds - are here interpreted as a tactic of rebellion distinct from typical insurgency tactics - in which the attacker has at least some chance of survival. For example, we see Al-Qa'ida as (in large part) a violent movement to overthrow the Saudi monarchy and other governments in Muslim countries, but not one relying on insurgency. Its suicide attacks in Tanzania, Kenya, Bali and the US were organized not to overthrow those governments, but rather to recruit support for movements that would challenge regimes (such as the Saudi) not based on their interpretation of Islam. The Al-Qa'ida attacks on the US in September 2001 also sought to reduce American military support for the Saudi regime. This perspective interprets Hamas and other Palestinian militias as engaged in a rebellion with two goals: to establish sovereignty in part (or all) of what is today Israel and her occupied territories and additionally to control the government of an eventual Palestinian state.

Although an ancient tactic in inter-state warfare, suicide attacks are relatively rare. They were not used as a modern tactic of internal rebellion until 1983 when Hizbullah employed suicide attacks to challenge the Israeli occupation of Lebanon. The Liberation Tigers of Tamil Eelam (LTTE) in Sri Lanka followed suit with the second

\footnotetext{
${ }^{3}$. Weinstein (forthcoming) shows greater variance in the degree to which insurgents are privy to the ideological message of their insurgency than suggested in this paragraph.
} 
major series of suicide attacks taking place beginning in 1987 (combined with conventional insurgency tactics). Suicide attacks have been employed (at least twice) in civil wars in only seven of the sixty-nine countries facing insurgencies in the last half of the $20^{\text {th }}$ century. Table 1 lists those seven countries, and the three with only a single recorded suicide attack.

Why are suicide attacks so rarely used by rebels? It is best to start with a profile of a suicide bomber as culled from the literature. He or she appears to be quite distinct from the typical recruit in a rural insurgency. ${ }^{4}$ The suicide bomber is more upscale economically, and more highly educated on average. (We surmise from this that he or she knows and relates to the ideological message of leadership, making grievances more consequential as a motivating force). ${ }^{5}$ The country of his victim is richer, and along with its wealth it has a competent army. Unlike the hopeless economic conditions that are ideal for insurgency, suicide bombers have moderate employment opportunities outside of the rebellion. The country's terrain is more easily accessed by the state. Comparing existing research on insurgencies with that on suicide attacks suggests a conjecture:

C1: When insurgency is favored, suicide terrorism decreases in value; where insurgency is disfavored, leaders need alternate means to succeed, and without a guerrilla force as a real threat, insurgents seek through spectacular heroic events demonstrating their tactical prowess and their commitment to the cause to gain advantage over a ruling regime.

The intuition is straightforward. ${ }^{6}$ Suicide bombing is a costly tactic, as it strips the insurgent organization of its human capital. It would be difficult if not impossible to

\footnotetext{
${ }^{4}$. Krueger and Maleckova (2002). While the jury is still out on whether suicide attackers are more upscale than the average person in their society, we can be more confident in claiming that he or she is more highly educated than the typical member of a rural insurgency.

${ }^{5}$. Insurgents are most likely to be male; suicide bombers draw from both genders.

${ }^{6}$. Wintrobe (2003) offers a similar conjecture in discussing the demand side for terror, that is, why leaders would ask for such sacrifices among their closest followers.
} 
recruit an impoverished young man who knows nothing about the ideals of the organization to volunteer for certain death. To be sure, as was apparently the case for the September 11, 2001 attacks, organizations can utilize ill-trained foot soldiers to support an operation that is led by adepts. And it is often the case that insurgent organizations can recruit volunteers who individually paid the costs of ideological training as a by-product of their religious or civic participation. But for all leaders, whether paid for by the organization or not, ideological training appears necessary, and there are organizational opportunity costs to losing these highly motivated and well-versed members. If sustaining the insurgency were easy, such losses would be wasteful. ${ }^{7}$

To test this conjecture, we used the FL dataset on insurgency onsets to predict suicide attacks in a particular country/year. We code the attack by the nationality of the perpetrators' organization rather than that of the victim. The motives of suicide attackers are complex, variable among attackers, and impossible to verify. But we hold it reasonable to assume that at least part of the motive is to challenge the perpetrators' "home" government, even when the targets are external. For even if the attackers wish to destroy the foreign government whose civilians they have killed, the attackers surely disapprove of the fact that their home governments receive support from that foreign country. They are acting as international agents of their country because the principals are in their assessment illegitimate or lack resolve. With this assumption, we can compare the country/years in which civil war onset took place with suicide attacks to see if suicide tactics are chosen in part as a consequence of the conditions that (dis)favor insurgency.

Table 2 compares the relationship of per-capita income with civil wars on the one hand and with suicide attacks on the other. ${ }^{8}$ The bottom panel reports on countries

\footnotetext{
${ }^{7}$. This reasoning is consistent with the non-use of kamikaze pilots by the Japanese military until American targets were too hard for conventional warfare. See Rosenthal (forthcoming) "Suicide Bombing: What is the Answer?"

${ }^{8}$. The Fearon/Laitin replication dataset ends in 1999. Yet many of the suicide missions reported in the ICT dataset are from 2000-2002. None of the results are qualitatively changed by adding the years 2000-2002 to
} 
currently experiencing civil wars, reporting the linear probability regression of a war indicator on GDP/capita (lagged one year, from the Penn World Tables) and an estimate of the proportion of mountainous terrain. GDP/capita has a consistently negative coefficient, both across countries and within countries over time (provided the regression allows for a trend by including the year as a predictor). Doubling GDP/capita reduces the probability of suffering a civil war by $8-10$ percentage points. The top panel, in contrast, shows that GDP/capita predicts a small and statistically insignificant change in the number of annual suicide attacks, both between countries and within countries over time (provided again that the regression allows for a trend increase in attacks in all countries). The cross sectional results also indicate that mountains do not predict suicide attacks, though they do predict civil wars. Taken together, the regression results indicate that the while poor, mountainous countries are likely to suffer civil wars, they are no more likely to suffer suicide attacks than richer, flatter countries.

The difficulty of conducting an insurgency is therefore a condition favoring the use of a costly tactic such as suicide attacks. This helps explain Israel, which has suffered most acutely from 100 such attacks during the sample period. Israel is a developed, relatively flat, small country with a brilliantly equipped army that has invested heavily in information. The conditions for insurgency in Israel, given the FL model, are not propitious. Under these conditions, standard rural guerrilla tactics are less likely to succeed, making suicide attacks a relatively effective tactic.

$C 1$, focusing on conditions unfavorable for insurgency as an incentive to employ suicide bombing, conditioned on there being a rebel movement, has some interesting exceptions. There are several cases where insurgency is disfavored, yet rebel groups have nonetheless emerged which do not employ suicide attacks. These cases include South Africa (the ANC), Spain's Basque Country (ETA), Japan (Aum Shinrikyo), Italy (Red Brigades), and Germany (Baader Meinhof). They suggest a second conjecture.

C2: Where conditions do not favor insurgency, suicide attacks remain extraordinarily difficult to sustain. The conditions that help sustain suicide attacks remain to be 
specified, but religious difference between the perpetrators and the victims helps to fulfill at least one of these conditions.

As with the case of the kamikaze pilots (Shinto pilots and largely Christian victims), the suicide attacks in our dataset were most often marked by a religious difference between the attackers and the victims. In Israel (Muslims vs. Jews), Sri Lanka (Hindus vs. Buddhists), Russia (Muslims vs. Eastern Orthodox Christians), and China (Muslims vs. Buddhists), religious difference marked perpetrator from victim. In the two cases from Saudi Arabia, although the forces of Al-Qa'ida seek to overthrow their coreligionists, their suicide attacks were aimed mostly against Christians. In Egypt, the suicide attack was by Muslim fundamentalists against the secular Muslims housed in the Egyptian embassy in Pakistan. While this does not support the conjecture, the argument about the importance of religion is not clearly undermined. Only the four cases perpetrated by the PKK (the Kurds) in Turkey are clearly disconfirming. But overall, 89.9 percent of the suicide attacks were aimed at victims whose religion was different from the attackers'. Table 3 presents data confirming this finding.

In contrast to suicide attacks, most insurgencies pit coreligionists against each other. In the FL data, only 18.4 percent of civil wars were fought between guerrillas predominantly from one religious group against armies of a state who were largely of a different religious group. In three of these cases, suicide attacks were used: Sri Lanka, Russia (Chechnya), and China (Xinjiang). Cases such as Nagorno-Karabakh in Azerbaijan, Srpska Republic in Bosnia, and rebellions in Nigeria, Philippines, Sudan, Cyprus and Bangladesh all pitted guerrilla armies against states that were led by people of a different religion. In these cases, however, conditions favoring insurgency were better, lessening the need for the extreme tactic of suicide attacks. Only the IRA in Northern Ireland is an example of low probability of insurgency along with religious difference, yet no suicide attacks. (This is the only case that meets the standards of $C 1$ and $C 2$, yet for which there have been no suicide attacks). If this conjecture proves to be correct, then the view that suicide attacks represent an outlier from the general conditions for insurgency is further confirmed. This conjecture suggests that only in the subset of 
rebellions where religious difference can be identified (or manufactured through relevant attacks on foreigners) are suicide attacks likely.

These conjectures and the evidence supporting them are provocative. Yet they have as yet little theoretical foundation, especially $C 2$. While one could easily hypothesize that attackers believe suicide attacks ensure eternal grace, a reward that would not come from killing coreligionists, one would face the challenge of explaining the extraordinary degree of religious conviviality in the world when such great rewards are available for killing one's neighbor (albeit of a different religion). To be sure, careful work in the social sciences, most notably in psychology, political science and economics has theorized about the questions that motivate this paper. ${ }^{9}$ However, the goal of this paper - to link radical religious organizations, rich countries, and the tactic of suicide attacks - transcends the disciplinary boundaries set by the current literature. Rather than focusing on the strategic rationality of suicide attacks (as do Pape 2005 and Bloom 2005), our focus is on the tactical choice of suicide attacks as compared to more conventional insurgency tactics.

\section{Section 2. Rational Martyrs and Terrorist Clubs: A Framework}

\section{Rational Martyrs ${ }^{10}$}

Much of the terror generated by suicide attacks comes from the idea of an army of theologically-motivated suicidal drones. Yet they could be rational, given either: a) a belief in the hereafter combined with a belief that the suicidal act will be rewarded in the hereafter, or b) altruism toward family or compatriots combined with a belief that the suicidal act will benefit family, community or some larger cause (Wintrobe 2003).

A given population is likely to hold at least some individuals who hold these beliefs. To be sure, mainstream Islam, like its theological cousins Christianity and

\footnotetext{
9. We build on the work especially of Merari (1990) in psychology, Pape (2003, 2005) and Bloom (2005) in political science, and Wintrobe (2003) in economics.

10. This discussion owes most of its content to a conversation with Larry Iannaccone.
} 
Judaism, sanctifies human life. ${ }^{11}$ Yet belief in the hereafter is widespread, as is belief in rewards in the hereafter. (In fact, most American Christians believe in heaven and most of those believers anticipate enjoying it (Iannaccone 1998)). In Islam, Sayyid Qutb's writings in Egypt in the 1950s on the "sacred jihad" lent support to suicide planners (Bergen 2002, 51). So while there is no clear religious connection to core suicide beliefs, aspects of all religions could be useful to radicals recruiting for suicide missions.

Altruism, combined with a belief that the welfare of others will be improved by the act - may apply to both religious and secular terrorists. In the case of suicide attacks not only is a sense of altruism required, but also an exaggerated belief in the benefit to their cause that will result from a successful attack. For instance, the September $11^{\text {th }}$ terrorists may have believed that their act would help topple the Saudi government. A Hamas suicide bomber might believe that a single destructive act would make some significant contribution to creating an Islamic state in Palestine. These beliefs stretch credulity but reflect a common bias of decision-makers in overestimating their potential to affect change (Jervis 1976).

The combination of beliefs necessary for a rational martyr is not unlikely. While we lack estimates of the incidence of different beliefs, only a small proportion of the population need be committed believers if an organization exists which can identify and recruit a cadre of suicide attackers. Iannaccone (forthcoming) points out that despite conventional wisdom about "brainwashing," research revealed that indoctrination played only a minor role in recruitment to US sects. Thus it may not be an unusual problem to find volunteers who prefer martyrdom to life, even without indoctrination. The real problem is in recruiting a reliable martyr. Radical religious groups have a strategic advantage in recruiting reliable martyrs, an insight which requires an exploration of the organizational structure of radical religious groups.

\footnotetext{
${ }^{11}$ Neither Christianity nor Judaism has consistently extended that sanctity to civilians of other religions. Samson, who clearly targeted civilians, is memorialized as a martyr by both Jews and Christians.
} 
Terrorist Clubs: Radical Religious Groups as Social Service Provision Clubs

Critical to our understanding of the role of Radical Islam in organizing armed rebellions is the recognition that these communities, like other religious sects, are commonly engaged in cooperative production of mutual insurance. Consider the following puzzle for the rational choice approach: religious sects prohibit common pleasurable behaviors and require sacrifices. Recruits must obey rules regarding diet, prayer, dress, hair, sexual practice, relations to constituted authority, and marital fidelity. Sacrifices such as burnt offerings irreversibly destroy resources. In European Jewry, a circumcision irreversibly labeled a child as Jewish, an act that might put his life at risk by destroying the option of pretending to be a gentile. A vow of fidelity or abstinence is also a form of sacrifice, since it permanently restricts activities. Volunteer work required of Mormons is a sacrifice of time with a foregone opportunity to accumulate human capital. Study in a religious institution represents a sacrifice of the alternative potential use of that time, be it in accumulation of human capital in secular studies or in accumulation of earnings.

Limiting choices and destroying resources are puzzles for social scientists trained in rational choice. Yet people voluntarily join groups that enforce prohibitions and require sacrifices. ${ }^{12}$ These groups stubbornly defy price theory, persisting in timeintensive activities like communal worship, Sabbath observance and dietary restrictions despite the historical increase in the shadow price of time. Strict sects show no sign of disappearing and those with the most demanding practices are growing. ${ }^{13}$ The modern Anabaptist traditions (such as the Amish, Mennonites and Hutterites) are holding their own while Ultra-Orthodox Jewry and Radical Islam are thriving, despite a multitude of time intensive requirements.

Iannaccone (1992) pointed out the puzzle of prohibitions and sacrifices and offered a solution, proposing that they are efficient institutions in the context of an economic club that provides services to members through cooperative production. This

\footnotetext{
${ }^{12}$ For a quasi-rational choice alternative, see Elster (1984).

${ }^{13}$ Iannaccone (1998) describes the growth of conservative sects worldwide (p. 1471).
} 
section summarizes his rationalization of religious sacrifices and extends the argument to cover militia activity as in Berman (2003).

\section{Clubs}

A social interaction model offers an explanation for sacrifices. Group members derive utility from (secular) consumption, $S$, and from time spent in religious activities, $R$, such as prayer and community service. They also gain utility from the level of a local public $\operatorname{good} A$.

$$
\begin{array}{r}
U_{i}=U\left(S_{i}, R_{i}, A\right) \quad \text { for } i=1 \text { to } N \text { members, } \\
U_{1}, U_{2}, U_{3}>0, U_{11}, U_{22}, U_{33}<0 .
\end{array}
$$

Good $A$ is nonrival and excludable, making it a $c l u b$ good. Members get $A$ from either a government, $G$, or the "club," $C$, which uses hours of religious activity as an input. Public safety is an example of a pure public good which could be provided by government or by a club, perhaps as a religious obligation. Welfare services, schools, hospitals and mutual insurance are examples of excludable, partially rival activities commonly provided by religious communities.

$$
\text { (2) } A=G+C\left(\left\{R_{i}\right\}\right)
$$

Members maximize utility subject to time and budget constraints. A fixed allocation of time, $T$, is split between the religious activity, $R$, and work hours, $H$, so that $R_{i}=T-H_{i}$. Income is earned from wages $w$ and spent on consumption of the secular good, $S$, at price $p$, so that

$$
\text { (3) } p S_{i}=w H_{i}=w\left(T-R_{i}\right) \text {. }
$$

Club good $C$ is produced by voluntary donation of time by members. These donations of time are difficult to monitor, since they are informal acts of charity, thus creating a free-rider problem. Sects apparently induce members to donate time by imposing a set of prohibitions which effectively reduce time devoted to activities outside the club, such as dietary restrictions, dress codes and sabbath restrictions. While this 
rationalization of religious prohibitions has no implications for our argument about suicide attacks, it should reinforce our faith in a club model of religious sects.

\section{Efficient Sacrifice}

Sacrifices are acts which irreversibly destroy value. They can be explained as an initiation rite that signals type (Camerer 1988, Iannaccone 1992) analogous to other forms of costly sacrifices that signal type, such as initiation rites in the military or hazing in fraternities. To explain sacrifices Iannaccone augments his base model with unobserved heterogeneity in the form of high wage (type 2) and low wage (type 1) individuals. High wage individuals choose less religious activity (in the upward-sloping part of a labor supply curve) as it is relatively more expensive for them, i.e., $R^{2}<R^{l}$ (Heterogeneity could alternatively be in preference for religious activities at the margin. Heterogeneity in wages is chosen mainly to simplify the exposition.) Assume that the value of the benign club good is given by the average of $R$, as would plausibly be the case in a mutual insurance club, where the average donation of time by members to mutual aid would matter.

\section{(4) $\quad C(R\rangle,)-C(R), \quad R=\sum_{-1}^{N} R / N$}

High wage - low $R$ individuals are potential "free-riders." They would like to join the high $R$ club and benefit from its high average level of religious activity. Members of the high $R$ (low wage) club would rather not admit the high wage types, as the reduction in the average level of religious activity would reduce club quality. Since access to the externality is excludable, the high $R$ (low wage) group can rid their club of free riders by requiring a costly initiation rite, or sacrifice, which will exclude low $R$ (high wage) individuals from joining, keeping $C$ high, at $C=R^{l}$. Unlike religious activity, $R$, the sacrifice benefits no one except through its role as a signal. Potential applicants must reveal their type, which is otherwise unobservable, when they make a decision to 
sacrifice, or not to sacrifice, time. ${ }^{14}$ A sacrifice inducing only low wage types to sacrifice is a separating equilibrium. ${ }^{15}$

\section{Recruiting}

We have argued that finding willing suicide attackers is probably not that difficult. The problem is in getting the right type. Radical religious sects are useful here as they use sacrifices as signals of commitment to sort prospective members on their unobserved attributes. Radical religious sects should therefore have an advantage in recruiting suicide attackers if they can design signals of commitment that will distinguish members who have the "right" beliefs from those who will pull out or even defect.

\section{The Production Function of Suicide Attacks}

Violent rebels such as guerrillas and terrorists are extremely sensitive to defection. Consider the logistics of organizing a suicide attack on some target where the potential victim can induce defection at any stage, from planning through the attack. There must be enough operatives involved to recruit a suicide attacker, train that attacker, record a video, observe the attacker to be sure his or her resolve does not waver, procure explosives, identify a target, send the attacker on their way and then make a public announcement taking credit. Assume that $N$ operatives are required, excluding the attacker. Each has some nonrival benefit $B$ from a successful attack.

\footnotetext{
${ }^{14}$ This view of a religious sect as social service provision clubs has testable implications. The stronger the sacrifice demanded of members, the higher the average level of voluntary religious activity and the greater the degree of mutual insurance. That implication is confirmed in Iannaccone's (1992) study of Christian denominations and supported casually in Berman's (2000) discussion of Ultra-Orthodox Jews. Among Muslims at least some radical sects are active at social service provision, including the Hamas, the Hizbullah and the Islamic Brotherhood in Egypt [Mishal and Sela (2000), Munson (2002)]. Other testable implications of the club approach to religion are supported by evidence on Ultra-Orthodox Jews (Berman 2000) and Indonesian Islamists (Chen 2003).

${ }^{15}$ For a proof see Iannaccone (1992). For a formal derivation of the optimal sacrifice and a graphical explanation see Berman (2000).
} 


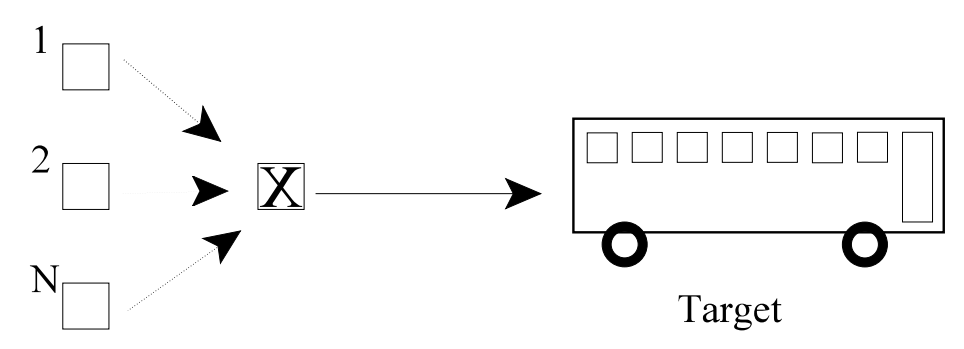

Conspirators

\section{Figure 1: Operatives and Target}

Any one of those $N$ operatives, including planners, has enough information to defect, destroy the operation, and collect a reward from the target's side, all with one phone call. Defection is not uncommon. Of the 189 Palestinian suicide attacks attempted between September 2000 and April 2003, fully 77 were prevented before the attacker detonated himself, presumably because someone provided information or defected (IDF figures, reported by Zeev Schiff, HaAretz, May 3, 2003). Sometimes the information may come from friends and family. ${ }^{16}$

Operatives jointly produce a club good. Each makes a binary choice of $R=1$ (loyalty) or $R=0$ (defection). Together they produce a good

$$
B(\{R i\})=B\left(\prod_{i=1}^{N} R i\right),
$$

where $B(1)$ is the value of a "successful" attack and $B(0)$ is that of a failure, so that $B(1)$ $>B(0)$. Assume that membership in this group is exclusive and that the benefits of success are shared in a nonrival manner among members (in prestige, political power, deterrence of an enemy).

\footnotetext{
${ }^{16}$ Although it is often noted that taped interviews with parents show great support for the heroic deeds of their children, these interviews are conducted after the attack. Parents know little beforehand, perhaps because they would have a powerful incentive to inform or induce defection.
} 
To induce defection, the target's side would be willing to pay an amount $D$ to prevent the damage inflicted, including both the direct damage and the indirect effect of a terrorized population. (Terrorism is probably a negative-sum activity as the replacement value of the damage to the victim may far exceed the value to operatives, $B$, so that $B<D$, even if $B(D)$ is an increasing function.)

Assume also that operatives have income from some outside sponsor (who values successful attacks) which is small but proportional $\alpha D$, where $0<\alpha<1$. Assume that a defector can extract the entire surplus, $D$, from the potential victim $D .{ }^{17}$

Now consider the payoffs of operatives in a club providing both benign public goods and the violent result of an attack. Substituting into equation (1), an operative who remains loyal enjoys utility

$$
U\left(\frac{\alpha D}{N}, 1, G+B(1)+C(\bar{R})\right) .
$$

where the first term is the payment from the outside sponsor split among $\mathrm{N}$ operatives which each consumes. The second term indicates the personal satisfaction for loyalty. The third reflects the augmented public good available to a loyal operative: government provisions, $G$, the benefit of a successful operation $B$, and the value of the benign club good $C$. A member who defects will be expelled from the community, receiving utility

$$
U(D+w, 0, G) .
$$

\footnotetext{
${ }^{17} \mathrm{We}$ assume away the hidden information problem faced by potential victims attempting to bribe club members into defecting. How would the potential victim know that someone claiming to be a defector was really planning to do any damage at all? That uncertainty prevents efficient Coasian bargaining, yet the fact that leaks occur and defection takes place indicates that defectors find some way of establishing credibility. Our results require only that the bribe offered to defectors be proportional to damage in some proportion exceeding $\alpha$.
} 
He consumes the damage value $D$ paid by the potential victim in addition to his outside wage, $w$, gets no satisfaction from doing his duty, and receives only government provided public goods. In all, each operative faces the incentive compatibility constraint

$$
U\left(\frac{\alpha D}{N}, 1, G+B(1)+C(\bar{R})\right) \geq U(D+w, 0, G)
$$

If that constraint fails for any of the $N$ operatives, then the operation fails and they are all exposed. The defection decision of the suicide attacker would look like (6) but with two differences. First, it would be augmented with terms reflecting altruism or the hereafter. Second, the left hand side reflecting utility in the present would be omitted.

\section{Suicide Attacks as a Tactical Choice}

To analyze when suicide bombing is the chosen tactic, we consider the possibility of apprehension. Let $p$ be the probability that the attacker is apprehended, exposing the identity of all operatives. Apprehension is far more dangerous for the organization than the attacker dying because an interrogated attacker exposes operatives. Assume that exposure implies both a failed attack and capture or death of all operatives, which we (prosaically) treat as setting utility to zero for exposed operatives.

Consider the conventional attack. Apprehension probability is a function of the inherent "hardness" of the target, $p(h)$. The difficulty, or "hardness," of the target is denoted by the real number $h$, which represents an index of defensive measures by the target (or its government) and topography (as in FL 2003). Governments can increase $p$ by investing in protective measures, increasing $h$. The expected utility of an operative from a conventional attack in the model including apprehension probability is

$$
\text { (7a) } \quad[1-p(h)] U\left(\frac{\alpha D}{N}, 1, G+B(1)+C(\bar{R})\right)
$$

In contrast, the utility of an operative from defecting is 
(7b) $U\left(D+w_{i}, 0, G\right)$.

These choices are illustrated by the solid lines in Figure 2, which graphs the utility of operatives against the damage done to victims for possible parameters. The steepest line is the utility gained by defecting (7b). It increases most quickly in damage, $D$, because the full value of $D$ is available to induce operatives to defect. It begins at a low level, for low $D$, because defectors draw no local public goods $(B$ or $C$ ) from the club. Thus defection is unattractive for low levels of damage, $D$.

For targets with a low probability of apprehension the utility-maximizing choice is the conventional attack (7b), illustrated by the upper line. Utility for loyal operatives using the conventional attack is high even at low $\mathrm{D}$ because they benefit from club goods $\mathrm{B}($.) and $\mathrm{C}($.). It increases slowly in $\mathrm{D}$ because the subsidy is only $\alpha \mathrm{D}(<\mathrm{D})$ and is split among $\mathrm{N}$ operatives.

As this figure shows, as the probability of apprehension, $p$, increases, expected utility falls; this is illustrated by the downward shift in the expected utility of a loyal operative. With high $p$ the conventional attack is incentive compatible only for a smaller range of targets $\left(0, D_{C}\right)$ for which expected utility from an attack ( $\left.7 a\right)$ exceeds that from defection(7b). This is how the model captures FL's results for insurgencies: topography, strong government and other environmental factors that raise $p$ will limit the targets that the insurgency can aspire to attack without operatives defecting. Thus one reason why insurgency decreases as GDP/capita rises is that government resources invested in apprehension will "harden" targets, limiting insurgencies to low damage activity.

At high apprehension probability (for hard targets), suicide attacks become relevant. They are less dangerous for the operatives (other than the attacker) but require them to lose a member and compensate the bereaved family, which we represent as a public bad $Z$ lost in a nonrival way by operatives. Utility of an operative from a suicide attack is then 
(7c) $U\left(\frac{\alpha D}{N}, 1, G+B+C(\bar{R})-Z\right)$.

Assume that the operatives have chosen a target of difficulty, $D$, and that they have a willing suicide attacker. They then choose between the maximum of the expected

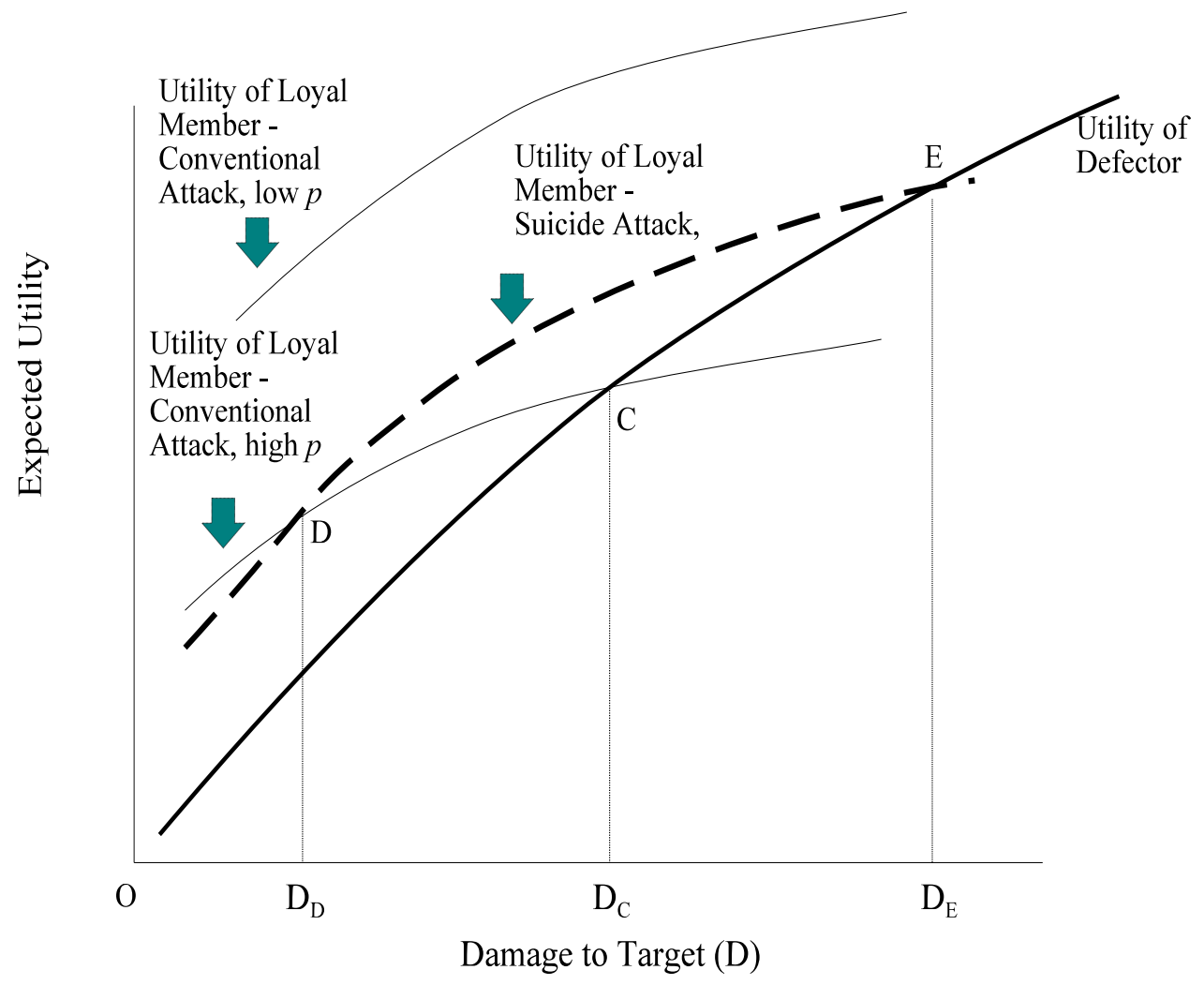

Figure 2: Conventional Attacks, Suicide Attacks and Damage

utility in expressions (7a), (7b) and (7c). The utility from a suicide attack is illustrated by the serrated line in Figure 2. The operative's utility is relatively low for the suicide tactic at low damage because of the loss of the attacker (-Z). Expected utility increases more quickly in damage for the suicide than for the conventional attack because the probability of apprehension affects only the conventional attack. Consider the case of a high $p$, which is relevant for a conventional attack but does not affect the utility from a suicide attack. 
To the right of the point labeled $\mathrm{D}$ (for targets with damage greater than $\mathrm{D}_{\mathrm{D}}$ ) suicide attacks are preferred over conventional attacks. ${ }^{18}$

At low probability of apprehension, the reduction in apprehension risk is not sufficient to compensate for the high cost to the club of losing a member, so suicide attacks are disfavored.

The analysis also addresses part of conjecture C1: Suicide attacks are favored when apprehension probabilities are high, for reasons adumbrated by FL: topography that makes apprehension likely or a government strong enough and well enough funded to harden targets. If we think of GDP/capita as a proxy for expenditure on apprehension probability then we find that unlike conventional insurgencies, which decline significantly in GDP/capita, suicide bombings are unaffected by GDP/capita, given that they hardly occur at all in poor countries. The model is consistent with that outcome, predicting that as defensive expenditures increase, the utility from a conventional attack shifts downwards so that the interval $\left(D_{D}, D_{E}\right)$ of incentive compatible suicide attack targets widens.

\section{Coreligionists are Soft Targets}

The analysis illustrated in Figure 2 provides an explanation for the striking results of Table 2. Think of coreligionists as soft targets. The typical problem in defending ("hardening") a crowded target is the infeasibility of screening all individuals with access to the target for every possible weapon. One solution is to predict which individuals are at highest risk of harboring violent intentions ("profiling") and then screen them carefully. Yet coreligionists are typically similar in appearance, making profiling extremely difficult. ${ }^{19}$

\footnotetext{
18. Note that in equilibrium $D$ may be higher in conventional attacks if computed in a loss-of-life algorithm We compare $D$ in market terms, i.e., how much state authorities would pay to prevent such an attack..

19 . This might explain the anomaly of Northern Ireland discussed in section 1, where suicide attacks are not used, even against members of the other religion. Diego Gambetta (personal communication, October 21, 2003 ) reports on research showing the strategic mimicking of identities so that potential targets of terror
} 
In the few prominent cases of suicide attacks on coreligionists, targets are well defended by means beyond profiling. That would be the case in the assassination of Egyptian President Anwar Sadat by the Egyptian Islamic Jihad, which was essentially suicidal, or in the assassination of Northern Alliance leader Ahmad Shah Masood by Al-Qa'ida suicide bombers disguised as journalists (Rashid 2002, p. 87). In both cases the attackers overcame any theological objections to killing Muslims, but may have chosen the suicide tactic because a conventional attack on those targets implied almost certain apprehension or death. Similarly with the LTTE assassination of Rajiv Gandhi on May 21, 1991, in which a Hindu killed a Hindu. As the favorite to win election as Prime Minister of India, he was an extraordinarily well defended target. This is also the case with the suicide attacks in Iraq after the American occupation of 2003 - although against coreligionists, the victims tend to be collaborators of the occupation, and thus better defended than oil pipelines for which suicide attacks are not used.

\section{Section 3. Testing the Extended Club Model of Terrorism}

We now turn to testable implications of our model, relying principally on data from Israel. Our first prediction is that suicide attacks are used disproportionately against hard targets. Palestinian insurgents in the West Bank and Gaza have a large choice of soft targets. Settlers and soldiers use roads that pass through heavily populated areas or through terrain that make them vulnerable to ambush. Settlements and military locations are also quite exposed and in proximity to large Palestinian populations. The result is that an attacker can fire a weapon or detonate a bomb remotely in such a way that makes escape relatively easy afterwards, and can then blend into the local population. In contrast, targets on the Israeli side of the "green" line are much "harder," posing much greater risks for the attacker. To reach the target requires passing through checkpoints and perhaps a security fence at which his weapon could be discovered. Once on the Israeli side, security forces and civilians can profile the attacker based on a "reading" of his ethnic markers. After an attack the attacker faces a heightened version of all those risks on the way back to safety.

avoid identification as either Protestant or Catholic. These strategies make profiling more difficult. 
Applying the analysis of Figure 2 to the Israeli case, the model predicts that attacks within the green line are more likely to use suicide tactics. Table 4 reports data on attacks and fatalities by location and method for the period from the beginning of the second intifada (September 2000) through July 2003. Attacks include all forms of violence toward Israelis and residents of Israel as recorded by the IDF, including suicide attacks but also shootings, roadside bombs, stone throwing and other tactics. The vast majority of recorded attacks are against soft targets in the West Bank and Gaza (96\%).

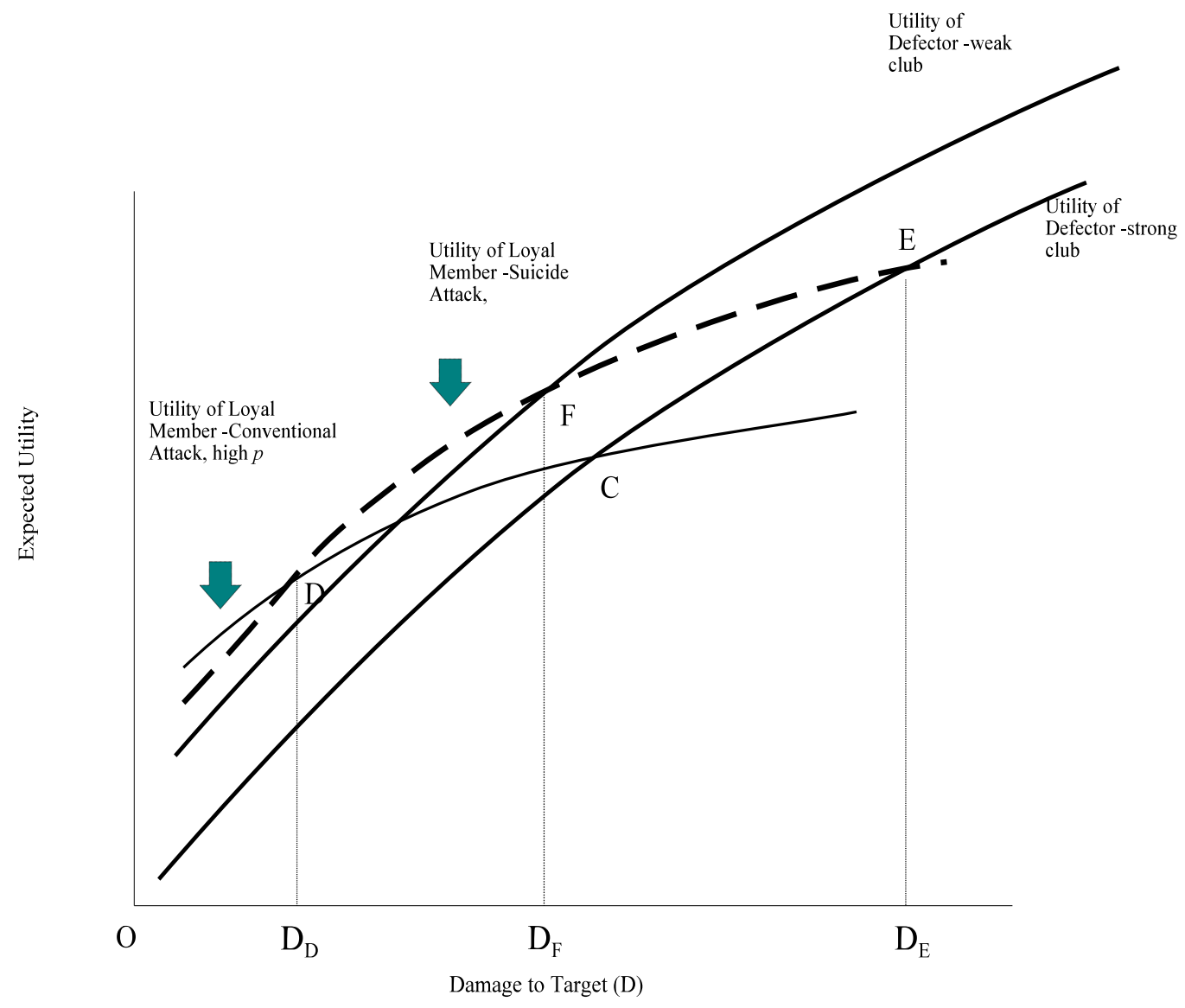

Figure 3: Strong Clubs Choose More, Deadlier Suicide Attacks 
The next column records fatalities due to attacks, which indicates that the majority of fatalities $(60 \%)$ are on the Israeli side of the green line. While there is no direct information here about choice of methods, the methods used on the Israeli side of the green line are clearly deadlier.

Conditional on fatalities, one can compare method by location. Suicide attacks killed eight people in the West Bank and Gaza while killing 401 on the Israeli side of the green line. That is to say, 17,405 attacks in the West Bank and Gaza resulted in eight deaths due to suicide attacks while 730 attacks on the Israeli side of the green line resulted in 401 deaths due to suicide attacks. The data show that suicide attacks are disproportionately used against the relatively "hard" targets on the Israeli side of the green line.

Two further implications also flow from the club model. First, the stronger the social service provision of the club, the greater the proportion of its attacks will be suicide attacks. Second, the stronger the social service provision of the club, the higher the quality of its volunteers for missions, and thus the more damaging will be its'suicide attack.

These predictions of the model come from the interaction of club strength, choice of tactics and damage. Clubs with the ability to screen out high wage operatives will have an advantage in such conspiracies. Consider heterogeneity in outside options, $w$, as above. Assume parameters are such that operatives with good outside options will defect while low wage types will organize a suicide attack (point F). I.e. there is some cutoff wage $w$ ' for which operatives are indifferent and $w^{L}<w^{\prime}<w^{H}$. A club with the capacity to extract signals of commitment (low wages) can successfully exclude those high wage applicants who haven't demonstrated organizational commitment. These groups can more successfully implement a suicide attack than terrorist groups that cannot screen out potential defectors.

Examination of (7) reveals why clubs put operatives with strong outside options (i.e., high w) under special scrutiny -they are more likely to defect. To be trusted, high wage operatives would need to compensate by making credible claims to organizational loyalty (e.g., that agents of the state murdered the claimant's brother or raped his/her sister). Thus 
high-wage recruits who pass the loyalty test should prefer to volunteer in low-wage highsacrifice organizations to protect themselves from defection.

Figure 3 also illustrates the second implication. If the environment favors suicide attacks for a weak club, the attacks carried out by a club which is strong (in social service provision) will also be deadlier. A weak club will use conventional attacks for relatively low damage targets, in the interval $\left(0, \mathrm{D}_{\mathrm{D}}\right)$ and switch to suicide attacks for higher damage targets, in the interval $\left(\mathrm{D}_{\mathrm{D}}, \mathrm{D}_{\mathrm{F}}\right)$. The most damage it can do is $\mathrm{D}_{\mathrm{F}}$, since larger targets will induce defection. A strong club has lower utility from defection for a given level of damage since members are selected to have worse outside options, as represented by the rightmost curve. That advantage is expressed as an expansion in its capability to carry out suicide attacks, with no effect on the decision to carry out conventional attacks. Both strong and weak clubs will carry out conventional attacks in the interval $\left(0, \mathrm{D}_{\mathrm{D}}\right)$. The strong club will use a wider range of targets for suicide attacks $\left(D_{D}, D_{E}\right)$, while the weak club will attack targets only in smaller damage range $\left(\mathrm{D}_{\mathrm{D}}, \mathrm{D}_{\mathrm{F}}\right)$.

Data from Israel and Palestine largely support these implications. Table 5 reports on organizations which have carried out both conventional and suicide attacks in Israel and Palestine. While they were selected according to the criterion of having carried out at least one suicide attack, Figure 3 indicates that this is the range of organizations for which the model can make predictions. We used the description of these groups in the ICT dataset (whose coders did not have our theory in mind) to see if there was any mention of social welfare provision by each organization, as an indicator of being a "strong club." As our model predicts, the two welfare providing organizations conduct more suicide attacks and have a higher yield per suicide attack than the three non welfare providing organizations.

Table 6 reports on the second of those implications, that strong clubs will choose the suicide attack tactic more often. Recall that this follows from Figure 4: strong clubs attack targets in the interval $\mathrm{D}_{\mathrm{F}}$ through $\mathrm{D}_{\mathrm{E}}$ for which only the suicide tactic is effective, while weak clubs cannot attack those targets for fear of defection. Table 6 lists the four Palestinian terrorist organizations. Hamas and the Palestinian Islamic Jihad have the highest proportion of 
suicide attacks, with $43 \%$ each. The PFLP follows with $13 \%$ and Fatah is the last, with $12 \%$. With the exception of the PIJ, the pattern is as predicted by the model. Hamas, the strong club, chooses the suicide attack tactic at least as often as the PIJ, which has very little if any social service provision, and more than Fatah and PFLP. The fact that the PIJ chooses suicide attacks so often despite its lack of a social service provision network may indicate that theology and indoctrination have a role in motivating suicide attackers. But our model helps explain, despite theological fervor, PIJ's relative lack of effectiveness (see Table 5). We therefore see these results as broadly consistent with the model's prediction that strong clubs will exploit their organizational advantage in suicide attacks.

\section{Section 4. Conclusion and Extensions}

This paper combines data on suicide attacks and a theory of clubs to address the question of when suicide attacks are employed as a tactic in an insurgency. It was motivated by several unusual patterns in the data. Though insurgencies typically target poor countries, suicide attacks are far more likely to target rich countries. Though insurgents often kill coreligionists, they seldom use suicide attacks to do so. Though many types of groups have grievances, suicide attacks are favored by the radical religious.

To make sense of these patterns, we modeled the choice of tactics by rebels. We first asked what a rational suicide terrorist would have to believe and discuss the role of religion in those beliefs. Standard rational choice accounts find that with plausible utility functions, recruitment of martyrs does not require appeals to irrationality or utter fanaticism. (But manipulating the utility function of martyrs adds little insight.) The real test of the rational model is not to explain recruitment per se, but rather recruitment of a type of martyr who will lower the likelihood of defection. To address this strategic problem, we proposed a club goods model that emphasizes the function of voluntary religious organizations as efficient providers of local public goods. The sacrifices which these groups demand are economically efficient and make them well suited for solving the extreme principal-agent problems in recruiting candidates for suicide attacks who will not defect. Thus, religious radicals are effective (but 
not necessarily unique) dispatchers of suicide bombers. The model also analyzed the choice of suicide attacks as a tactic, predicting that suicide will be used when targets are well protected and when damage is great. Those predictions are consistent with the patterns that we earlier described. Our model had testable implications for tactic choice and for damage achieved by terrorists, which are supported by the data from the Israel/Palestine conflict.

Our model is not without problems. First, it is not obvious that our tests of the model would work in cases beyond Israel. We therefore need to ask what insight this model gives for interpreting other cases. Here we address several cases - Sri Lanka, Russia and Iraq - where suicide missions have taken place under conditions somewhat different from those in Israel. ${ }^{20}$

In Sri Lanka, the LTTE's Black Tiger's use of suicide attacks highlights how specific our model is to asymmetric warfare. The Sri Lankan government is not strong enough to control the territory from which the LTTE operate, so that capture of an attacker does not trigger assassination or capture of operatives, as would likely be the case in Israel or Iraq. The Sri Lankan environment favors standard insurgency, which for the most part is what has been occurring since 1984. That insurgency is not carried out by an organization which fits the club model: the LTTE is not religious, does not provide social services exclusively to members and does not send valuable members on suicide attacks (Bloom 2005).

Even so, the club model provides insight into this case. For one, suicide attacks are reserved for targets for which conventional attack is unlikely to succeed. In the early years of the Tamil insurgency, as Swamy reports, most of the activity was intra-Tamil warfare, as many groups vied to become the monopoly representative of the Tamil population of Sri Lanka. For all the intra-Tamil killing, there were no cases of suicide attacks. Nor are there suicide attacks in the civil war within civil war taking place among Tamil Tigers in 2005, on the question of negotiation strategy with the Sri Lankan state. As Hopgood $(2005,72)$ points out, when the SLA launched Operation Liberation in mid-1987, which established military camps in the heart of the LTTE-controlled zones, the Black Tigers were formed to use suicide

${ }^{20}$. Kalyvas and Sánchez-Cuenca (2005) provide analysis of cases where suicide missions might have been used but weren't. 
attackers (as substitutes for missiles) to go after these targets, as an alternative to cruise missiles (Hopgood 2005, 75). Second, the LTTE has recognized the immense problem of defection. Gambetta (2005) points out that the Black Tigers "are subject to a commitment pressure by having a ritual dinner with their leader, Pirabakaran, before the missions - a subsequent defection would imply a catastrophic loss of faith." This suggests that our model's focus on the problem of defection is not unique to the Israel case. Finally, closer scrutiny reveals that the secular nature of the Tigers can be overstated. As their war developed against the Sri Lankan state, several observers have noted the use of Hindu symbols for purposes of recruitment, and that they rely on the language of religious martyrdom to justify and reward the sacrifice.

Similar anomalies appear in the case of the two Chechen wars (1994-1996; 1999-) in Russia. In the first Chechnyan war, the so-called boyeviki (insurgents), according to Lieven "lack a military hierarchy and organization, formal training, formal commanders and tactical doctrine..." And Lieven also notes that there were numerous reports in the first war where "death squads shoot people [other Chechens] on the square, kill members of parliament inside the parliament building, and, finally shoot a dozen disloyal policemen at the city's police headquarters - the killing of Chechens by Chechens...In front of video cameras, Shamil Basayev executed an old man who had been a local administrator in his native village..." This was hardly a war organized by a coherent organization seeking to maximize effect by going after spectacular hard targets (Tishkov, 2004, quoting Lieven).

Yet, again, our model captures key strategic elements in the Chechen insurgency. First, the primary targets for Chechen suicide missions are Russian civilian and military complexes, which are hard targets. The largely Eastern Orthodox Russian police and military profile Muslims from the Caucasus and keep them under strict surveillance. Conversely, soft targets (for example, the so-called Chechen traitors to the cause, who are not well-protected by the Russian army) do not merit suicide missions. Second, Chechen suicide attacks did not begin until after Wahhabi fundamentalists, funded by the bin Laden network, began operating in Chechnya. They provided locals with needed social services. There was, for example, a $\$ 1,000$ reward for new converts, and families of converts got stipends of $\$ 100$ per month 
during the war. In exchange, the Wahhabi demanded sacrifices. Women were forced out of the job market. The new religious leaders demanded "compulsory prayers, Arab clothes, a ban on shaving, banishment of the ustazes [Sufi shaykhs]," and clean breaks from family (Tishkov 1004, 172-6). These Wahhibis, Tishkov shows, have been the source of the suicide strategy. In sum, suicide missions in the Chechen rebellion are connected with hard targets and socialbenefit providing clubs.

In Iraq, where suicide attacks after the American-led invasion occurred after the period covered in our dataset, it is too early to put any of our hypotheses to test. The big problem that our model will need to face is that after the data are in, the modal country will become Iraq and many of these attacks will be against coreligionists. These data will compel model adjustment. Yet there are signs that the model has explanatory power in this case. It would predict that the suicide attacks aimed at property and people close to the "Green Zone" (where Americans are the hardest targets of all) are the work of religious radicals, organized as clubs, from abroad. Although many targets are co-religionists, they tend to be American collaborators who are better protected than other Iraqis and therefore hard targets. Meanwhile, the model would predict that the rump Ba'athists are conducting a parallel insurgency of conventional attacks against soft targets: mortar attacks on villages, ambushes on the route to Baghdad from the airport, and bombs planted on oil pipelines. If this division of insurgent labor turns out to be correct, it would add credence to our model.

A second problem for our model concerns the relationship of wealth to tactic choice. In the model poverty should breed terrorism as it lowers the outside options of club members. That would appear to be inconsistent with the findings of Berrebi (2003) and Krueger and Maleckova (2003) who find that leaders and suicide attackers tend to have about the same income levels as their neighbors, and higher educational levels. It may be critical here to distinguish between incentives to join the club, incentives to defect and the selection that goes on inside. Self-selection would suggest that the leaders have a higher skill level. One wouldn't think that bin Laden's lieutenants would choose illiterate Afghan Jihadists for flight school in Florida if disaffected students in Europe were available. Even among attackers, those chosen to carry out suicide attacks are carefully screened to reduce their probability of defection or 
capture, either by ensuring that they were trusted members of the organization or by their having some motivation for revenge, such as losing a family member to the enemy. The accuracy of warnings of attack in Israel indicates that defectors and informants exist. What this suggests is that operatives can be relatively well-to-do but they would be reliable to the extent that they have credibly foresworn outside options.

More theoretical and empirical work is in order to account formally for nonreligiousbased clubs and the reliance on cadres with high outside options. Here we give only intuitions for future modeling. We still lack a standard dataset of suicide attacks in particular and terrorist attacks in general. ${ }^{21}$ The data on total suicide attacks are very sensitive to definition. In the dataset presented herein, we did not count self-immolation or waves of soldiers marching into sure-death tank formations (as in the Iran-Iraq war) as examples of suicide attacks, and they surely bear a family resemblance to the phenomenon that we have isolated. But even with data on the dependent variables presented herein, there ought to be further tests of our model. For example, an observable implication of our model is that the more benign local public goods (mutual insurance, physical protection) provided to members, the lower the defection rate. That would be especially true when the state and market do not provide substitutes to these services, as in failed states. Another observable implication is that the higher the potential damage caused by the attacks, the greater the incentive to defect. These implications require testing beyond the Palestinian case.

While work still needs to be done for a fuller understanding of the logic of suicide attacks, this paper, through the use of a club model combined with a distinction between hard and soft targets helped explain three puzzles in tactical choice of rebels. (1) Suicide attacks have seldom been used against coreligionists because they are soft targets and can be attacked with less costly tactics. (2) Suicide attacks target rich countries, again because they present the harder targets. (3) Suicide attacks have been used disproportionately by radical religious groups because as strong clubs they can more easily overcome the defection constraint.

\footnotetext{
${ }^{21}$. RAND analysts, for example, advertise a dataset of suicide attacks with far more observations than reported here, but the raw data are not publicly available (Hoffman 2003).
} 


\section{REFERENCES}

Azzi, Corry, and Ronald G. Ehrenberg, "Household Allocation of Time and Church Attendance," Journal of Political Economy, 83 (1975), 27-56.

Bergen, Peter L., Holy War, Inc.: Inside the Secret World of Osama Bin Laden (New York: Touchstone, 2002).

Berman, Eli, "Sect, Subsidy and Sacrifice: An Economist's View of Ultra-Orthodox Jews," Quarterly Journal of Economics, 115(3) (August, 2000).

"Hamas, Taliban and the Jewish Underground: An Economist's View of Radical Religious Militias,” NBER WP 10004, (October 2003). and Ara Stepanyan, "How Many Radical Islamists? Indirect Evidence from Five Countries." UCSD mimeo (October 2003).

Berrebi, Claude (2003) "Evidence about the link between Education, Poverty and Terrorism among Palestinians," Princeton University mimeo.

Bloom, Mia (2005) Dying to Kill (New York: Columbia University Press)

Camerer, Colin, "Gifts as Economic Signals and Social Symbols," American Journal of Sociology XCIV (1988): S180-214.

Chen, Daniel, "Economic Distress and Religious Intensity: Evidence from Islamic Resurgence During the Indonesian Financial Crisis," MIT mimeo, November 2003.

Chwe, Michael (2001) Rational Ritual (Princeton: Princeton University Press)

Collier, Paul and Anke Hoeffler (2001) "Greed and Grievance in Civil War" http://econ.worldbank.org/progarms/library

Cutter, Ann (1998) "Tamil Tigresses: Hindu Martyrs" http://www.columbia.edu/cu/sipa/PUBS/SLANT/SPRING98/article5.html

Elster, Jon (1984) Ulysses and the Sirens: Studies in Rationality and Irrationality (Cambridge: Cambridge University Press).

Fearon, James D. and David D. Laitin (2003) “Ethnicity, Insurgency and Civil War" American Political Science Review 97(1): 75-90 (February 2003).

Gambetta, Diego (2005) Making Sense of Suicide Missions (Oxford: Oxford University Press).

Hamermesh, D. and N. Soss (1974) "An Economic Theory of Suicide," Journal of Political Economy, January/February.

Hassan, Nasra, “An Arsenal of Believers: Talking to the 'human bombs.'” The New Yorker, November 19, 2001.

Hoffman, Bruce (2003) “The Logic of Suicide Terrorism” The Atlantic Monthly

Iannaccone, Laurence R. "Sacrifice and Stigma: Reducing Free-riding in Cults, Communes, and Other 
Collectives," Journal of Political Economy, C (1992), 271-291. "Introduction to the Economics of Religion," Journal of Economic Literature, XXXVI (1998), 1465-1496. (forthcoming) "The Market for Martyrs." George Mason University mimeo.

Jervis, Robert (1976) Perception and Misperception in International Politics (Princeton: Princeton University Press).

Juergensmeyer, Mark. Terror in the Mind of God: The Global Rise in Religious Violence, (Berkeley: University of California Press, 2000).

Krueger, Alan B. and Jitka Maleckova, "Education, Poverty, Political Violence and Terrorism: Is there a Causal Connection? NBER WP \#9074, July 2002(b). , "Does Poverty Cause Terrorism?" The New Republic, June 2002(a).

Mishal, Shaul and Avraham Sela, The Palestinian Hamas: Vision, Violence and Coexistence (New York: Columbia University Press, 2000).

Munson, Ziad "Social Movement Theory and the Egyptian Muslim Brotherhood," Sociological Quarterly 42(4), January 2002.

Pape, Robert A. (2003) “The Strategic Logic of Suicide Terrorism” American Political Science Review 97(3): 343-61.

Pape, Robert A. (2005) Dying to Win (New York: Random House)

Rashid, Ahmed, Taliban: Militant Islam, Oil and Fundamentalism in Central Asia, (New Haven: Yale, 2000). , Jihad: The Rise of Militant Islam in Central Asia, (New Haven: Yale, 2002).

Schiff, Zeev and Ehud Yaari, Intifada, The Palestinian Uprising: Israel's Third Front (New York: Simon and Schuster, 1989).

Smith, Adam, An Inquiry into the Nature and Causes of the Wealth of Nations (Reprint of 1776 version) (New York: Modern Library, 1965).

Sprinzak, Ehud, "Rational Fanatics," Foreign Policy, September/October 2000.

Swamy, M. R. Narayan (1994) Tigers of Lanka: From Boys to Guerrillas (Delhi: Konark Publishers)

Tishkov, Valery (2004) Chechnya: Life in a War-Torn Society (Berkeley: University of California Press).

Weber, Max, Economy and Society (Berkeley: University of California Press, 1978).

Weinstein, Jeremy (forthcoming) Inside Rebellion: The Political Economy of Rebel Organization (Cambridge: Cambridge University)

Wintrobe, Ronald, "Can Suicide Bombers be Rational?" (March 5, 2003) unpublished manuscript, University of Western Ontario. 


\section{Hard Targets}

\section{Eli Berman \\ David Laitin}

\section{Data Appendix}

This paper merges two datasets on suicide terrorism. The first is from Pape (2003, 357-60). The second is from the International Policy Institute for Counter-Terrorism, at the Interdisciplinary Center Herzliya, available on the web at: [http://www.ict.org.il/]. This version was downloaded Sept. 12, 2003. The dataset goes from 1980 through 2002, with the most recent suicide attack on November 22, 2002. However, there are only nine events recorded from 1980-87, so in effect the dataset covers fifteen years, 1988-2002.

\section{Some Descriptive Statistics on Suicide attacks}

While suicide attacks (given the spectacular and deeply troubling moral narratives that accompany the reporting of them) dominate our headlines, they are a rarely employed tactic in insurgencies and cause few deaths. Tables A1 and A2 provide some descriptive statistics from our dataset. There have been 236 recorded suicide attacks in eleven countries, with 42 percent of the cases coming from Israel. ${ }^{22}$ Using just the integrated ICT dataset, suicide attacks represent less than 10 percent of all terrorist acts in the dataset. ${ }^{23}$ Using the combined dataset, suicide attacks have accounted for 5,922 deaths, nearly half of them from a single day (September 11, 2001). Although the use of suicide attacks has tended to increase year-by-year

\footnotetext{
22. Most datasets classify the perpetrators as coming from "the West Bank". For purposes of this paper, the Palestinians are under the de facto control of Israel, and are fighting an insurgency either to take control over all of Palestine (capture the center) or to build a Palestinian state on some portion of current-day Israel. Suicide bombing is a tactic in the pursuance of this goal.

23. Criteria for what constitutes a terrorist act, and therefore a collection of the universe of cases of terrorist acts, are much disputed. In the ICT dataset, for example, there is a racialist bias. African terrorism appears if blacks kill white civilians, but not if blacks kill black civilians. There is also a pro-state bias, as state induced terrorism (e.g. the Sinhalese burning of Tamil properties in 1983) is not included. Suicide attacks, however, are less controversial for purposes of objective coding, making them more susceptible to descriptive statistical analysis.
} 
over the past two decades (Table A2), if we consider the fact that since 1945 insurgencies have caused over sixteen million deaths, the tactic of suicide bombing appears as only a small footnote to that enormous death toll. ${ }^{24}$

\section{Coding Rules}

1. There were 56 observations that were in both datasets.

2. There were 40 observations in the ICT dataset for the year 2002, which was past Pape's range, and we included these in the full dataset.

3. There were 132 observations in Pape that were not in ICT, and we added them.

4. There were 9 observations in ICT in the years of Pape's range, but not included, and we added them.

5. There were 2 events in Pape (Dec 15, 1981, Iraqi Embassy; Aug 15, 1993, Egypt) with insufficient information, and were not included in the merged dataset

6. There were 2 events in Pape (March 27, 2001, Hamas in Jerusalem) that was considered a single event in ICT, and we considered it a single event in the merged dataset

7. There was a single observation in Pape, on Al-Qa'ida bombing of the US Embassies in Kenya and Tanzania; we counted this as two events (as they occurred in different countries, and I have a unique value for country of attack), and divided the total deaths in half, for each country. 8. Whenever Pape and ICT differed on deaths, we averaged the two death-counts, so some death counts are not integers.

9. Whenever Pape and ICT differed on group name of perpetrators, we deferred to ICT (all cases were in Middle East, and ICT had stronger explanations for choosing group) 10. For Sri Lanka, we counted as a missing value on religious differentiation if the bombing was into a crowd that was random in regard to religion; a genuine religious difference between perpetrator and target if the target was material (a ship; a government building; an army base) but controlled by the state; n.b. that there is religious differentiation if the bombing was aimed at a Muslim politician even he were from the North.

\footnotetext{
${ }^{24}$. In rather bad social science form, all too many papers seek to account for this outlier, obscuring the general situation for suicide attacks of high publicity and low deaths.
} 
Table A1

SUICIDE MISSIONS: SOME DESCRIPTIVE STATISTICS

\begin{tabular}{|l|l|}
\hline Number of Suicide Missions in Full Dataset & 236 \\
\hline Number of Suicide Missions in ICH Dataset & 107 \\
\hline Total Number of Terrorist Acts in ICH Dataset & 1427 \\
\hline $\begin{array}{l}\text { Percentage of Suicide Missions of All Terrorist Attacks in } \\
\text { ICH Dataset }\end{array}$ & 7.4 \\
\hline $\begin{array}{l}\text { Total Deaths from all suicide attacks (without 9/11/01) in } \\
\text { full dataset }\end{array}$ & $5,922(2,603)$ \\
\hline $\begin{array}{l}\text { Average Number of Deaths Per Attack (without 9/11/01) in } \\
\text { full dataset }\end{array}$ & $25.1(11.1)$ \\
\hline
\end{tabular}

\section{Table A2}

SUICIDE ATTACKS BY YEAR AND TOTAL KILLED

\begin{tabular}{|l|l|l|}
\hline Year & Total Number of Attacks & Total Number Killed \\
\hline 1983 & 6 & 420 \\
\hline 1984 & 2 & 19 \\
\hline 1985 & 18 & 209 \\
\hline 1986 & 3 & 11 \\
\hline 1987 & 1 & 18 \\
\hline 1988 & 0 & 0 \\
\hline 1989 & 0 & 0 \\
\hline 1990 & 2 & 6 \\
\hline 1991 & 5 & 73 \\
\hline 1992 & 1 & 1 \\
\hline 1993 & 3 & 25 \\
\hline 1994 & 10 & 117.5 \\
\hline 1995 & 19 & 225 \\
\hline 1996 & 18 & 283 \\
\hline 1997 & 8 & 50.5 \\
\hline 1998 & 13 & 400.5 \\
\hline 1999 & 16 & 64.5 \\
\hline 2000 & 23 & 195 \\
\hline 2001 & 48 & 3564 \\
\hline 2002 & 40 & 239 \\
\hline & & \\
\hline
\end{tabular}




\section{Tables}

Table 1: COUNTRIES WITH ORGANIZATIONS THAT ORGANIZED SUICIDE ATTACKS

\begin{tabular}{|l|l|}
\hline COUNTRY & NUMBER OF SUICIDE ATTACKS \\
\hline ISRAEL & 100 \\
\hline SRI LANKA & 75 \\
\hline LEBANON & 30 \\
\hline TURKEY & 13 \\
\hline SAUDI ARABIA & 8 \\
\hline RUSSIA & 4 \\
\hline INDIA & 3 \\
\hline EGYPT & 1 \\
\hline CHINA & 1 \\
\hline ALGERIA & 1 \\
\hline
\end{tabular}

Source: See Appendix 
Table 2: Suicide Attacks, Civil Wars and GDP/capita across Countries 1945-1999

\begin{tabular}{|c|c|c|c|c|c|c|}
\hline & \multicolumn{2}{|l|}{ Total } & \multicolumn{2}{|c|}{$\begin{array}{l}\text { Between } \\
\text { Country }\end{array}$} & \multicolumn{2}{|c|}{ Within Country } \\
\hline $\begin{array}{l}\text { Dependent } \\
\text { Var: }\end{array}$ & & $\begin{array}{l}\text { w/ } \\
\text { trend }\end{array}$ & & $\begin{array}{l}\text { W/ } \\
\text { moun- }\end{array}$ & & $\begin{array}{l}\text { w/ } \\
\text { trend }\end{array}$ \\
\hline Suicide attacks & & & & & & \\
\hline GDP/capita & .0097 & .0050 & .003 & .004 & .045 & -.010 \\
\hline & $(.0028)$ & $(.0022)$ & $(.009)$ & $(.009)$ & $(.011)$ & $(.016)$ \\
\hline Mountains & & & & $\begin{array}{l}.005 \\
(.006)\end{array}$ & & \\
\hline Year & & $\begin{array}{l}.0016 \\
(.0003)\end{array}$ & & & & $\begin{array}{l}.0024 \\
(.0005)\end{array}$ \\
\hline $\begin{array}{l}\text { Dependent } \\
\text { Var: }\end{array}$ & & $\begin{array}{l}\text { w/ } \\
\text { trend }\end{array}$ & & $\begin{array}{l}\mathrm{w} / \\
\text { moun- } \\
\text { tains }\end{array}$ & & $\begin{array}{l}\text { w/ } \\
\text { trend }\end{array}$ \\
\hline War Indicator & & & & & & \\
\hline GDP/capita & $\begin{array}{l}-.069 \\
(.004)\end{array}$ & $\begin{array}{l}-.084 \\
(.004)\end{array}$ & $\begin{array}{l}-.096 \\
(.019)\end{array}$ & $\begin{array}{l}-.089 \\
(.019)\end{array}$ & $\begin{array}{l}.042 \\
(.007)\end{array}$ & $\begin{array}{l}-.109 \\
(.010)\end{array}$ \\
\hline Mountains & & & & $\begin{array}{l}.026 \\
(.013)\end{array}$ & & \\
\hline Year & & $\begin{array}{l}.0048 \\
(.0003)\end{array}$ & & & & $\begin{array}{l}.0066 \\
(.0003)\end{array}$ \\
\hline $\mathbf{N}$ & 6373 & 6373 & 6373 & 6373 & 6373 & 6373 \\
\hline Countries & 156 & 156 & 156 & 156 & 156 & 156 \\
\hline
\end{tabular}

Source: FL replication data is described in Appendix. Suicide is the count of suicide attacks in a country-year. Results are qualitatively robust to extension through 2001 (using 1999 $\mathrm{GDP} /$ capita figures) and to the exclusion of Israel. 
Table 3

RELIGIOUS DIFFERENCES BETWEEN INSURGENTS (SUICIDE BOMBERS) AND TARGETED VICTIMS

\begin{tabular}{|l|l|l|}
\hline & INSURGENCY & SUICIDE ATTACK \\
\hline PERCENTAGE OF & $18.4 \%$ & $89.9 \%$ \\
ONSETS (ATTACKS) & & \\
WITH RELIGIOUS & & \\
DIFFERENCE & & \\
\hline
\end{tabular}

Table 4

ATTACKS ON ISRAELI RESIDENTS BY LOCATION AND TACTIC

\begin{tabular}{l|c|l|c|} 
& \multicolumn{2}{|c|}{ Sept 2000 through July 2003 } & $\begin{array}{l}\text { (of which) } \\
\text { Fatalities due } \\
\text { to Suicide } \\
\text { Attacks }\end{array}$ \\
\hline Location & Attacks & Fatalities & 8 \\
\hline West Bank and Gaza & 17,405 & 341 & 401 \\
\hline Inside Green Line & 730 & 511 & 409
\end{tabular}

Sources: Attacks, fatalities and fatalities due to suicide attacks inside green line are from the Israel Defense Forces spokesperson's office, as reported by Nadav Shragai in Ha'Aretz, September 26, 2003. Fatalities in West Bank and Gaza due to suicide attacks are from the ICT data for that period described in the Appendix.

Table 5

\section{SOCIAL ORGANIZATION OF TERRORIST GROUPS} AND EFFICIENCY OF SUICIDE ATTACKS

\begin{tabular}{l|l|l|l|} 
& $\begin{array}{l}\text { Social Welfare } \\
\text { Institutionalization* }\end{array}$ & $\begin{array}{l}\text { Suicide Attacks } \\
\text { Accomplished }\end{array}$ & $\begin{array}{l}\text { Average } \\
\text { deaths/attack }\end{array}$ \\
\hline Hamas & Yes & 50 & 7.8 \\
\hline Hizbullah & Yes & 30 & 22 \\
\hline Palestinian Islamic Jihad & No & 23 & 3.8 \\
\hline $\begin{array}{l}\text { Fatah (Fatah, Fatah Tanzim, } \\
\text { and Martyrs of al-Aqsa }\end{array}$ & No & 20 & 2.8 \\
\hline PFLP & No & 2 & 5.5 \\
\hline
\end{tabular}

Source: See Appendix for data sources.

* In its review of terrorist organizations, the ICT mentions the provision by the organization of social welfare benefits to ordinary citizens, going beyond ideological, religious and military tasks. 
Table 6

TERRORIST ORGANIZATIONS IN ISRAEL

SELECTION OF SUICIDE BOMBINGS AS AN INSURGENCY TACTIC

\begin{tabular}{|l|l|l|l|}
\hline Group & All terrorist attacks & Suicide Attacks & Percentage \\
\hline Hamas & 115 & 50 & $43 \%$ \\
\hline PIJ & 54 & 23 & $43 \%$ \\
\hline $\begin{array}{l}\text { Fatah (Fatah, Fatah } \\
\begin{array}{l}\text { Tanzim, and Martyrs } \\
\text { of al-Aqsa) }\end{array}\end{array}$ & 161 & 20 & $12 \%$ \\
\hline PFLP & 16 & 2 & $13 \%$ \\
\hline
\end{tabular}

For all terrorist attacks, data from ICT dataset (http://www.ict.org.il/), data as analyzed on their dataset on October 23, 2003. For suicide attacks, data are the combined ICT and Pape dataset. First step, we took the data from Table 6 for column two. Second step, we asked for all terrorist events in the ICT dataset for each of the four organizations listed on the table. These data are on column 1. We had to omit Hizbullah from these calculations because the ICT dataset reports fewer total incidents of Hizbullah terror than the combined ICT/Pape dataset on Hizbullah suicide attacks. 